\section{Health profile differences between recipients and non-recipients of the Brazilian Income Transfer Program in a low-income population}

\author{
Diferenças no perfil de saúde entre beneficiários \\ e não-beneficiários do programa Bolsa Família \\ em uma população de baixa renda
}

\section{Diferencias en el perfil de salud entre beneficiarios y no-beneficiarios del programa Bolsa Familia en una población con bajos ingresos}

Jeremy A. Labrecque 1

Jay S. Kaufman 1

\begin{abstract}
We investigated the relationship between living in a household that receives the Brazilian Income Transfer Program (Bolsa Família, in Portuguese - BF), a Brazilian conditional cash transfer program, and aspects of health and whether these relationships are heterogeneous across the 27 Brazilian states. According to data from the 2013 Brazilian National Health Survey, 18\% of households participated in BF. Among households with household per capita income below BRL 500, many aspects of health differed between people living in BF and non-BF houses. For example, BF households were less likely to have medical coverage but more likely to have visited the doctor in the last 12 months as well as being more likely to smoke and less likely to do exercise. They ate nearly one less serving of fruits and vegetables a week but were less likely to substitute junk food for a meal. They reported worse self-rated health but did not differ importantly on reporting illnesses. Moderate amounts of heterogeneity in the difference in health characteristics were found for some variables. For instance, medical coverage had an $I^{2}$ value of $40.7 \%$ and the difference in coverage between BF and non-BF households ranged from - 0.09 to -0.03. Some illnesses differed qualitatively across states such as high cholesterol, asthma and arthritis. This paper is the first to outline the health profile of people living in households receiving payments from a cash transfer program. It is also the first to find geographic heterogeneity in the relationship between a cash transfer program and health variables. These results suggest the possibility that the effect of cash transfer programs may differ based on the population on which it is implemented.
\end{abstract}

Health Policy; Population Characteristics; Government Programs

\author{
Correspondence \\ J. A. Labrecque \\ Department of Epidemiology, Biostatistics and Occupational \\ Health, McGill University. \\ 1020 avenue des Pins Ouest, Purvis Hall, Room 16B, Montreal / \\ Quebec - H3A 1A2, Canada. \\ jeremy.labrecque@mail.mcgill.ca \\ 1 Department of Epidemiology, Biostatistics and Occupational \\ Health, McGill University, Montreal, Canada.
}




\section{Introduction}

In 2004, Brazil implemented a conditional cash transfer program (CCT) called Bolsa Família (BF; Brazilian Income Transfer Program). The program has grown to be the biggest in the world, paying over USD 9 billion to 14 million households in 2016 alone (Brazilian Comptroller General of the Union. http://www.portaltransparencia.gov.br, accessed on 14/Jan/2017). Most studies of BF have understandably focused on child health because the conditions of the program are targeted toward them. Little research has been conducted on adults. One study found that people receiving BF had a higher $\mathrm{TB}$ cure rate than those not receiving $\mathrm{BF} 1$. An ecological study found that increased coverage by $\mathrm{BF}$ was associated with a decrease in leprosy detection rates 2 . Another study examined the nutritional status in adults receiving BF but did not have a control group 3. To our knowledge, no other study has either investigated the effect of $\mathrm{BF}$ in adults or described how people receiving $\mathrm{BF}$ differ from non-BF recipients.

While the relationship between CCTs and child health has been well-studied, results have been inconsistent 4 . Some results suggest a reduction in growth/nutritional status 5 , some no difference 6 and some suggest an increase in growth/nutritional status 7 . One possible explanation is that all these studies are estimating the same quantity but obtain different results due to the methods used and random variation. Though the methods employed and chance variation certainly influence all results, another explanation is that there is important geographic heterogeneity in the causal effect or association of BF with child growth. Therefore, studies in different settings are estimating different quantities. Effect heterogeneity could also partially explain the wide range of results found in a recent metaanalysis of the effect of different CCT programs on child growth in a number of different countries 4.

Brazil is well-suited for the investigation of geographic heterogeneity because its 27 states have stark differences in socioeconomic and demographic characteristics. For example, the state with the highest per capita gross domestic product 8 has a value higher than many European countries including Portugal and the Czech Republic, but the state with the lowest per capita gross domestic product is closer to Guatemala or Nigeria (World Bank. http://data.worldbank.org/indicator/NY.GDP.PCAP. $\mathrm{CD}$, accessed on $24 / \mathrm{Feb} / 2017$ ). Brazil is not only economically but also racially diverse. In the northern region, about $80 \%$ of the population identify themself as black or mixed, while in the southern region, $80 \%$ identify themself as white (Brazilian Institute of Geography and Statistics IBGE. http://www.ibge.gov.br/home/estatistica/populacao/condicaodevida/indicadoresminimos/ sinteseindicsociais2016/default_tab_xls.shtm, accessed on 16/Dec/2016). Brazil's three other regions fall somewhere in between.

The following description of BF is drawn from the law that established the $\mathrm{BF} 9$ and the Brazilian Federal Savings Bank website (http://www.caixa.gov.br/programas-sociais/bolsa-familia/Paginas/ default.aspx, accessed on 14/Jan/2017). In 2013, all households with a household per capita income (HPCI) below BRL 70 were eligible to receive a monthly BRL 70 payment, the unconditional component of BF. Households with children under 18 years with a HPCI below BRL 140 were also available for an additional payment as longs as the child met specific conditions. For every child under 16 years (to a maximum of five children) who attended yearly health check-ups, adhered to the vaccine schedule and maintained a school attendance of $85 \%$ or above, a monthly payment of BRL 32 was made. For every child of either 16 or 17 years (to a maximum of two children) who maintained a school attendance of $85 \%$ or above, a monthly payment of BRL 38 was made. For families who, after adding all BF payments to their income, still had a HPCI below BRL 70, a complementary payment was made to bring their HPCI up to BRL 70.

This manuscript has two main objectives. The first is to determine whether Brazilians receiving BF have a different health profile than Brazilians not receiving BF. This will provide policy makers more knowledge about the health status of BF recipients as well as provide knowledge about potential confounders for future researchers. The second objective is to see whether, given the socioeconomic and demographic heterogeneity seen across Brazil's 27 states, there is corresponding geographic heterogeneity in the association between $\mathrm{BF}$ and health indicators across states. Evidence of this type of heterogeneity would suggest that research on $\mathrm{BF}$ in one part of Brazil may not be transportable to another part or that transportability would require conditioning on some ecological or composi- 
tional covariates. Furthermore, heterogeneity within Brazil would make it more difficult to use evidence on the effectiveness of a conditional cash transfer in one country to justify its implementation in another country.

\section{Methods}

\section{Data source}

We used data from the 2013 Brazilian National Health Survey (PNS, acronym in Portuguese). It was a household-based, national survey that interviewed 205,546 people in 64,348 households and included an extended interview with 60,202 people 10 . The purpose of the survey was to get an overall picture of the multiple facets of Brazilians' health, health-service use and medical care. It was conducted between August 2013 and February 2014 by trained fieldworkers. It was composed of 21 modules covering household and community characteristics, general health and socioeconomic characteristics of household members and more specific modules such as exposure to accidents and women's health. The first two modules describe the household, the next nine modules are applied to every household member, and the last nine more specific health modules are applied to one household member above 18 years selected at random.

The sample was drawn from the Master Sample of the IBGE' Integrated System of Household Surveys which is a sampling strategy used to ensure national representativeness 10 . The sampling is conducted at three levels. At the first level, census sectors are selected through proportional probability by random sampling. Within each selected sector, a random sample of households is chosen. At this stage, all household members complete the nine modules asked of all household members. The last stage selected one household member at random to complete the extended survey.

\section{BF definition}

Though the survey specifically asked about household income received from BF, when the data were made public, this value was combined with the values from questions on "interest from savings accounts and other financial investments, dividends, social programs, unemployment insurance, secured insurance or other income?". This created the difficulty of disentangling the values received from $\mathrm{BF}$ and from other sources in this combined variable. Firstly, we assumed that among poor Brazilians, very few would have payments from financial dividends. Secondly, the minimum monthly payout from unemployment insurance is the minimum wage (BRL 678), therefore we eliminated any values from the combined variable that were equal to or over that value. We downloaded a database of all the payments made by BF in July 2013 and found that $99.5 \%$ of the payments made were under $B R L 500$. We retained only values in the combined variable that matched payment amounts from the $\mathrm{BF}$ database and compared the resulting distribution to the distribution found in the BF databases. Lastly, we eliminated all payments of BRL 300 made in the PNS data to avoid misclassification with another cash transfer program, Garantia-Safra (GS; Crop-Guarantee), that paid farmers who lost crops to drought. We preferred to remove payments of this value because in the BF data from the national database BRL 300 payments accounted for $0.003 \%$ of all BF payments while GS made up $5 \%$ of all cash transfer payments by the Federal Government.

\section{Measures}

All variables except weight, height and body mass index (BMI) were obtained via questionnaire. Trained field employees that worked in the IBGE, administered the questionnaires and recorded the responses on a personal digital assistant 11 . Nutritional questions regarding numbers of servings per week were measured by asking the respondents how many times a week they ate a specific food item and how often each day they ate it. An electronic scale was used to measure weight and a portable stadiometer was used to measure height. Education was classified as low for people with 9 years of 
school or less, medium for people with more than 9 years but less than or equal to 12 years of schooling and high for people with a higher degree to be consistent with the Brazilian education system 12.

\section{Statistical analysis}

The main statistics of interest were differences in health and health behaviors between households receiving $\mathrm{BF}$ and households not receiving $\mathrm{BF}$ as well as the heterogeneity between states in these measures. For the purposes of this analysis, only people who answered the extended survey were used because most variables of interest were only assessed in the extended interview. We estimated the prevalence of BF in every state to compare to the values reported by the government. In the main analysis the sample was restricted to households with a HPCI below BRL 500. Prevailing differences were estimated for binary outcomes and simple differences for count or continuous outcomes both crude and adjusted for basic demographic variables (sex, household per capita income, number of people living in the household, age, race, education and whether the household was in an urban or rural area). For binary outcomes, we estimated logistic regression models and subsequently calculated the difference in marginal predicted probabilities when setting those that received BF and those that did not receive $\mathrm{BF}$, both in the entire country and in each state, where the covariates were set to their observed values. Rather than using these estimated differences, we chose to use empirical Bayes to shrink the estimates toward the grand mean. This introduces bias into the estimates but reduces the overall mean square error 13 . For the count and continuous outcomes we repeated this procedure but with Poisson and linear regression, respectively. The degree of heterogeneity in the associations between the Brazilian states was quantified using Cochran's Q 14 and I-squared statistics 15. In order to incorporate the complex sampling design used for the PNS and to get the appropriate standard errors, we used the survey package in R. All data analyses were performed in R (http://www.r-pro ject.org). The code for running the entire analysis (including downloading the data) can be found at https://github.com/jerbreck/BF_hetereogeneity.

The data were publicly available and therefore their use did not require ethics approval.

\section{Results}

The PNS survey visited 81,357 households and found 11,363 (14\%) to be unoccupied 11. Among occupied households, 64,348 (92\%) agreed to the short questionnaire applied to all household members. After selection of a household member for the long questionnaire, 4,146 (6\%) declined to answer the long questionnaire. The percentage of those that declined varied by state from $1 \%$ to $18 \%$. Among occupied households, the response rate for the long questionnaire was $86 \%$.

The distribution of the payments received from social programs was very similar to the distribution of payments made by BF (Figure 1). The three largest spikes in the histograms are at the same locations and have very similar relative magnitudes. Also, the tail of the distributions above BRL 150 are similar. A few notable differences between the distributions can be found between BRL 75-100 and BRL 175-200. The differences may be due to the rounding of payment amounts.

Table 1 shows the proportion of people receiving BF in different demographic and socioeconomic groups in households with a monthly per capita income below BRL 500. White Brazilians are nearly half as likely to live in a BF household as black or mixed race people. Around $40 \%$ of people between 18 and 30 years of age live in BF households but BF participation decreases strongly after 50 years likely because of a lack of children in the household and because Brazil offers a pension to all elderly who live in a household earning under one-quarter of the minimum monthly wage per capita. $\mathrm{HPCI}$ is also highly related to receiving BF although households with a reported HPCI below BRL 100 were less likely to receive BF than households between BRL 100-300. This demonstrates that either households are not reporting the same income to the PNS than they did to the Brazilian Ministry of Social Development or they are staying on BF even after their HPCI improves. BF participation increases monotonically with the number of people in the household. BF participation in rural areas is nearly the double of the participation in urban areas. Those with less than a high school degree were $8 \%$ more likely to be BF participants than those with a high school degree or higher. 


\section{Figure 1}

Histogram of distribution of the Brazilian Income Transfer Program (Bolsa Família - BF) payments as reported by respondents in the Brazilian National Health Survey (1a) and according to the Brazilian Transparency Portal (1b).

1a) Brazilian National Health Survey

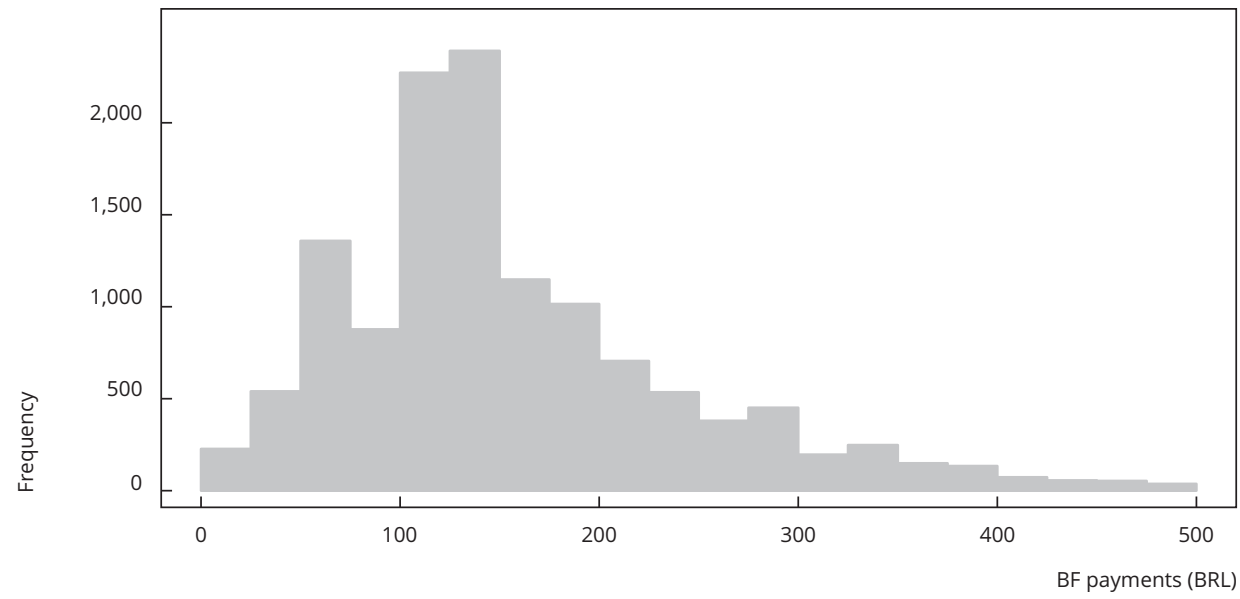

1b) Brazilian Transparency Portal

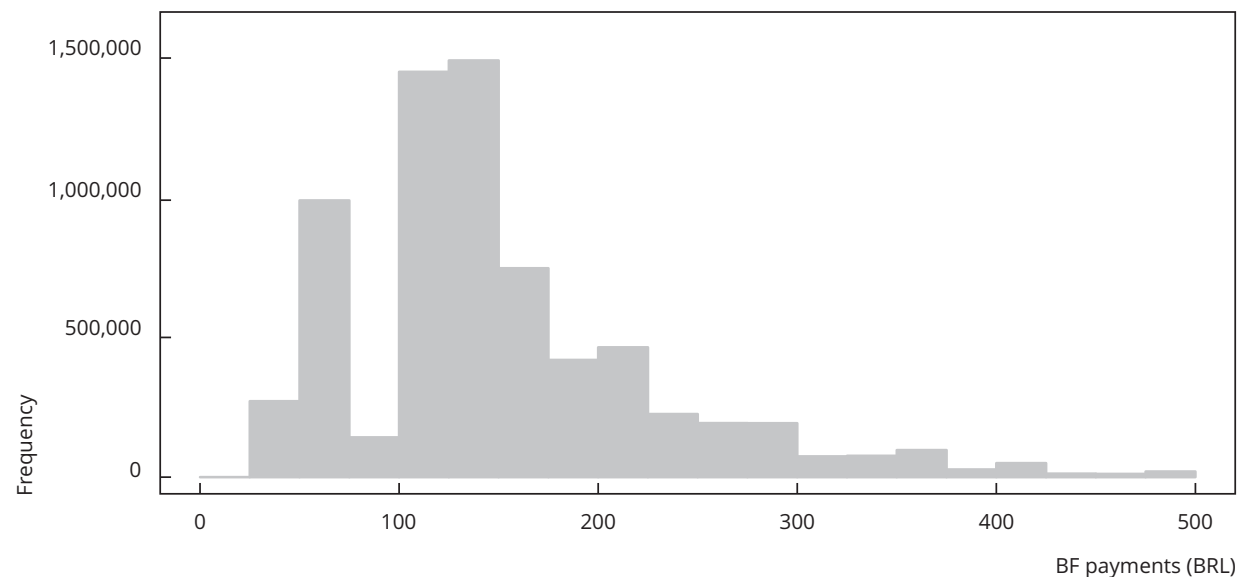

According to data from the Brazilian Ministry of Social Development, 23\% of households in Brazil participated in BF in 2016 (http://aplicacoes.mds.gov.br/sagi/RIv3/geral/index. php? relatorio $=153 \&$ file $=$ entrada, accessed on $02 / \mathrm{Feb} / 2016$ ). According to estimates derived from the 2013 PNS data, the participation rate was $18 \%$. These differences may be due to the changing BF participation rates from 2013 to 2016.

Overall, the associations between living in a BF household and the health indicators investigated here tend to show they have poorer health indicators and behaviors (Table 2). In terms of medical services use, people living in households that receive BF were less likely to be hospitalized or to have seen a doctor in the previous year. However, when adjusted for basic demographic and socioeconomic variables, residents of BF households were more likely to have seen a doctor in the previous year. They were also less likely to have any type of private health insurance and more likely to have had contact 


\section{Table 1}

\begin{tabular}{|c|c|}
\hline Variable & $\begin{array}{l}\text { Probability of living in a household receiving BF } \\
\qquad(95 \% \mathrm{Cl})\end{array}$ \\
\hline \multicolumn{2}{|l|}{ Race } \\
\hline Black & $0.36(0.33,0.39)$ \\
\hline White & $0.20(0.19,0.22)$ \\
\hline Mixed & $0.37(0.35,0.38)$ \\
\hline \multicolumn{2}{|l|}{ Age (years) } \\
\hline $18-30$ & $0.38(0.36,0.40)$ \\
\hline $31-50$ & $0.41(0.39,0.42)$ \\
\hline $51-70$ & $0.18(0.17,0.20)$ \\
\hline$>70$ & $0.09(0.07,0.11)$ \\
\hline \multicolumn{2}{|l|}{ Sex } \\
\hline Male & $0.30(0.28,0.31)$ \\
\hline Female & $0.31(0.30,0.32)$ \\
\hline \multicolumn{2}{|l|}{$\mathrm{HPCl}(\mathrm{BRL})$} \\
\hline $0-100$ & $0.29(0.27,0.30)$ \\
\hline $101-200$ & $0.48(0.46,0.51)$ \\
\hline $201-300$ & $0.33(0.31,0.35)$ \\
\hline $301-400$ & $0.22(0.20,0.24)$ \\
\hline $401-500$ & $0.20(0.18,0.22)$ \\
\hline \multicolumn{2}{|c|}{ People living in household } \\
\hline 1 & $0.05(0.04,0.06)$ \\
\hline 2 & $0.13(0.12,0.14)$ \\
\hline 3 & $0.26(0.24,0.27)$ \\
\hline 4 & $0.37(0.35,0.39)$ \\
\hline 5 & $0.45(0.42,0.48)$ \\
\hline$>5$ & $0.49(0.46,0.52)$ \\
\hline \multicolumn{2}{|l|}{ Location } \\
\hline Urban & $0.26(0.25,0.27)$ \\
\hline Rural & $0.47(0.46,0.49)$ \\
\hline \multicolumn{2}{|l|}{ Education } \\
\hline Low & $0.33(0.31,0.35)$ \\
\hline Medium & $0.32(0.31,0.34)$ \\
\hline High & $0.25(0.23,0.26)$ \\
\hline
\end{tabular}

95\% Cl: 95\% confidence interval; $\mathrm{HPCl}$ : household per capita income.

Note: these values are weighted to take the survey design into account.

with a community health worker. People from BF households were approximately a half-centimeter shorter and had an equal or higher BMI than people from non-BF households. People from BF households also had riskier health behaviors being slightly more likely to smoke and less likely to exercise compared to non-recipients of BF. Nutritionally, people from BF households ate one less serving of fruits and vegetables per week but were also less likely to report substituting junk food for a meal. With regard to health problems, no large differences emerged between people from BF and non-BF households with the exception of self-rated health where they were $4 \%$ less likely to say their health was good or very good.

Next, we examined the heterogeneity in associations between states. Brazil has 27 states that differ markedly in their economic situation, demographics and medical systems. These differences can be seen in the heterogeneity between states in health indicators (Table 3). The association between 


\section{Table 2}

Unadjusted and adjusted differences $(95 \% \mathrm{Cl})$ between households receiving the Brazilian Income Transfer Program (Bolsa Família - BF) and those not receiving BF across a range of health indicators.

\begin{tabular}{|c|c|c|}
\hline Health indicator & Unadjusted difference & Adjusted difference * \\
\hline \multicolumn{3}{|l|}{ Health services use } \\
\hline Medical coverage & $-0.09(-0.11,-0.07)$ & $-0.06(-0.07,-0.05)$ \\
\hline Hospitalized & $-0.01(-0.02,0.00)$ & $-0.01(-0.01,0.00)$ \\
\hline Visited doctor in the last 12 months & $-0.02(-0.03,0.00)$ & $0.02(0.01,0.04)$ \\
\hline Visited community health worker & $0.09(0.07,0.11)$ & $0.06(0.04,0.09)$ \\
\hline \multicolumn{3}{|l|}{ Anthropometrics } \\
\hline Height (cm) & $-0.07(-0.44,0.29)$ & $-0.53(-0.81,-0.24)$ \\
\hline Weight (kg) & $-0.97(-1.46,-0.48)$ & $-0.13(-0.68,0.42)$ \\
\hline $\mathrm{BMI}\left(\mathrm{kg} / \mathrm{m}^{2}\right)$ & $-0.34(-0.52,-0.15)$ & $0.12(-0.04,0.28)$ \\
\hline \multicolumn{3}{|l|}{ Health behaviors } \\
\hline Smoking & $0.03(0.01,0.04)$ & $0.01(0.00,0.02)$ \\
\hline Drinking & $0.01(0.00,0.03)$ & $0.01(-0.01,0.02)$ \\
\hline Exercise & $-0.03(-0.04,-0.01)$ & $-0.02(-0.03,0.00)$ \\
\hline \multicolumn{3}{|l|}{ Nutrition } \\
\hline Fruits/Vegetables (servings/week) & $-2.10(-2.49,-1.72)$ & $-0.93(-1.29,-0.56)$ \\
\hline Meat (servings/week) & $0.15(-0.02,0.31)$ & $-0.07(-0.22,0.08)$ \\
\hline Sweets and pop (servings/week) & $0.14(0.00,0.30)$ & $-0.09(-0.23,0.05)$ \\
\hline Substituted junk food for a meal & $-0.04(-0.05,-0.02)$ & $-0.03(-0.05,-0.01)$ \\
\hline \multicolumn{3}{|l|}{ Health problems } \\
\hline Poor self-rated health & $0.00(-0.02,0.02)$ & $-0.04(-0.06,-0.02)$ \\
\hline High blood pressure & $-0.08(-0.10,-0.06)$ & $0.01(-0.01,0.02)$ \\
\hline Diabetes & $-0.04(-0.05,-0.02)$ & $-0.01(-0.02,0.01)$ \\
\hline High cholesterol & $-0.05(-0.07,-0.03)$ & $-0.01(-0.03,0.01)$ \\
\hline Cardiac problem & $-0.01(-0.02,-0.01)$ & $0.00(-0.01,0.01)$ \\
\hline Asthma & $-0.01(-0.02,0.00)$ & $-0.01(-0.02,0.00)$ \\
\hline Arthritis & $-0.03(-0.04,-0.02)$ & $0.00(-0.01,0.01)$ \\
\hline Depression & $-0.01(-0.01,0.00)$ & $0.00(-0.01,0.01)$ \\
\hline Mental illness & $0.00(-0.01,0.00)$ & $0.00(-0.01,0.00)$ \\
\hline Cancer & $-0.01(-0.01,0.00)$ & $-0.01(-0.01,0.00)$ \\
\hline Any type of handicap & $-0.04(-0.06,-0.03)$ & $-0.01(-0.02,0.01)$ \\
\hline
\end{tabular}

95\% Cl: 95\% confidence interval; BMI: body mass index.

Note: all estimates are risk differences unless otherwise indicated.

* Adjusted for sex, household per capita income, number of people living in the household, age, race, education and whether the household was in an urban or rural area.

being from a BF household and both private health insurance and having visited a community health worked both has an I-squared value above $40 \%$ indicating that between state variation accounted for over $40 \%$ of the overall variance. This can be seen in the difference between the state with the lowest difference and high difference in Table 3. For example, being from a BF household was not related to whether someone had had contact with a community health worker in Sergipe; in Acre however, people from BF households were $13 \%$ more likely to have had contact with a community health worker. Only small differences were seen between states with regard to hospitalization and having visited a doctor in the previous 12 months. Differences in both height and weight showed moderate heterogeneity across states as well ranged from large negative differences to positive differences. Very little heterogeneity existed between states when considering health behaviors. Exercise had the highest I-squared value; however, in absolute terms, the difference between the lowest and highest state was only $3 \%$. Nutrition also did not show much heterogeneity. Of interest, although not many 
Table 3

Heterogeneity in health characteristics between states (Cochran's Q and 12) and highest and lowest differences between people living in Brazilian Income Transfer Program (Bolsa Família - BF) and non-BF households.

\begin{tabular}{|c|c|c|c|c|c|c|c|}
\hline \multirow[t]{2}{*}{ Variable } & \multirow[t]{2}{*}{ Cochran's Q } & \multirow[t]{2}{*}{ p-value } & \multirow[t]{2}{*}{12} & \multicolumn{2}{|c|}{ Lowest difference } & \multicolumn{2}{|c|}{ Highest difference } \\
\hline & & & & States & Difference & States & Difference \\
\hline \multicolumn{8}{|l|}{ Health services use } \\
\hline Medical coverage & 45.1 & 0.01 & 40.7 & RS & $-0.09(-0.13,-0.05)$ & $\mathrm{RR}$ & $-0.03(-0.05,-0.01)$ \\
\hline Hospitalized & 25.1 & 0.51 & 1.2 & Various & $-0.01(-0.02,0.01)$ & Various & $0.00(-0.02,0.01)$ \\
\hline $\begin{array}{l}\text { Visited doctor in the last } 12 \\
\text { months }\end{array}$ & 20.5 & 0.77 & 0.0 & $\mathrm{AM} / \mathrm{MG}$ & $0.01(-0.02,0.04)$ & Various & $0.03(0.00,0.07)$ \\
\hline Visited community health worker & 50.6 & 0.00 & 46.4 & SE & $0.02(-0.04,0.07)$ & $A C$ & $0.13(0.07,0.19)$ \\
\hline \multicolumn{8}{|l|}{ Anthropometrics } \\
\hline Height (cm) & 47.4 & 0.01 & 47.9 & AP & $-1.17(-2.05,-0.42)$ & $A C$ & $0.09(-0.59,0.93)$ \\
\hline Weight (kg) & 47.6 & 0.01 & 49.4 & PR & $-2.14(-4.36,-0.17)$ & MS & $0.76(-0.72,2.70)$ \\
\hline BMI (kg/m²) & 34.8 & 0.12 & 30.5 & PR & $-0.13(-0.81,0.27)$ & MS & $0.26(-0.07,0.77)$ \\
\hline \multicolumn{8}{|l|}{ Health behaviors } \\
\hline Smoking & 28.3 & 0.34 & 9.9 & RJ & $0.00(-0.03,0.02)$ & Various & $0.02(0.00,0.05)$ \\
\hline Drinking & 22.7 & 0.65 & 0.0 & Various & $0.00(-0.02,0.03)$ & Various & $0.01(-0.01,0.03)$ \\
\hline Exercise & 38.2 & 0.06 & 35.9 & Various & $-0.03(-0.08,0.00)$ & AC/PA & $0.00(-0.03,0.04)$ \\
\hline \multicolumn{8}{|l|}{ Nutrition } \\
\hline Fruits/Vegetables (servings/week) & 25.4 & 0.50 & 0.0 & BA & $-1.31(-2.42,-0.60)$ & RO & $-0.65(-1.38,0.48)$ \\
\hline Meat (servings/week) & 33 & 0.16 & 25.5 & MG & $-0.20(-0.71,0.10)$ & SP & $0.05(-0.23,0.53)$ \\
\hline Sweets and pop (servings/week) & 31.8 & 0.20 & 16.2 & AM & $-0.21(-0.53,0.04)$ & MA & $0.18(-0.14,0.68)$ \\
\hline Substituted junk food for a meal & 36.5 & 0.08 & 27.6 & $\mathrm{RO} / \mathrm{AM}$ & $-0.05(-0.09,-0.01)$ & RN & $0.00(-0.04,0.05)$ \\
\hline \multicolumn{8}{|l|}{ Health problems } \\
\hline Self-rated health good/very good & 43.2 & 0.02 & 38.3 & $\mathrm{RR}$ & $-0.07(-0.13,-0.03)$ & SP & $0.01(-0.04,0.07)$ \\
\hline High blood pressure & 33.4 & 0.15 & 23.5 & Various & $0.00(-0.03,0.04)$ & Various & $0.02(-0.01,0.06)$ \\
\hline Diabetes & 56.2 & 0.00 & 49.4 & AM/AL/SP & $-0.04(-0.07,-0.01)$ & $\mathrm{MA} / \mathrm{CE}$ & $0.02(-0.02,0.06)$ \\
\hline High cholesterol & 73.6 & 0.00 & 62.9 & MT & $-0.10(-0.14,-0.06)$ & PE & $0.03(-0.01,0.07)$ \\
\hline Cardiac problem & 22.9 & 0.64 & 0.8 & Various & $0.00(-0.01,0.01)$ & Various & $0.00(-0.01,0.01)$ \\
\hline Asthma & 62 & 0.00 & 52.3 & PR & $-0.04(-0.06,-0.02)$ & MA/SE & $0.02(0.00,0.04)$ \\
\hline Arthritis & 60 & 0.00 & 54.1 & SC & $-0.06(-0.10,-0.03)$ & SE & $0.03(0.00,0.07)$ \\
\hline Depression & 32.6 & 0.17 & 26.6 & RR/PB/MG & $-0.01(-0.03,0.01)$ & $\mathrm{PI}$ & $0.01(-0.01,0.03)$ \\
\hline Mental illness & 47.3 & 0.01 & 48.8 & Various & $-0.01(-0.01,0.00)$ & Various & $0.00(-0.01,0.01)$ \\
\hline Cancer & 44.1 & 0.01 & 47.8 & $\mathrm{PR} / \mathrm{MT}$ & $-0.02(-0.04,-0.01)$ & Various & $0.00(-0.02,0.01)$ \\
\hline Any type of handicap * & 51.3 & 0.00 & 46.9 & DF & $-0.05(-0.09,-0.01)$ & $\mathrm{RR}$ & $0.04(0.00,0.09)$ \\
\hline
\end{tabular}

BMI: body mass index; States: AC - Acre; AL - Alagoas; AM - Amazonas; AP - Amapá; BA - Bahia; CE - Ceará; DF - Federal District; MA - Maranhão; MG - Minas Gerais; MS - Mato Grosso do Sul; MT - Mato Grosso; PA - Pará; PB - Paraíba; PE - Pernambuco; PI - Piauí; PR - Paraná; RJ - Rio de Janeiro; RN - Rio Grande do Norte; RO - Rondônia; RR - Roraima; RS - Rio Grande do Sul; SC - Santa Catarina; SE - Sergipe; SP - São Paulo. Note: differences are risk differences unless otherwise indicated.

* Mental or physical.

differences were observed by BF status for health problems when all the data was pooled, there was moderate to large amounts of heterogeneity by state. The most important heterogeneity was found for high cholesterol, in which the variability between states was $63 \%$ of the total variability. This heterogeneity can be seen in the difference between Mato Grosso, where people from BF households were $10 \%$ more likely to have been diagnosed with high cholesterol, and Pernambuco, where people from $\mathrm{BF}$ households were 3\% more likely to be diagnosed with high cholesterol. Strong heterogeneity such as this was found for diabetes, asthma, arthritis, mental illness, cancer and having any type of handicap. Although the differences reported between the lowest and highest difference states for mental illness and cancer seem small, the small risk differences still exhibit moderate heterogeneity. 
Lastly, we inspected the state-by-state differences in four variables with high I-squared values to assess whether these were similar between states (Figure 2). There did not appear to be a strong overall pattern demonstrating that the four selected variables showed similar patterns between states. In all states, private health insurance was lower among people receiving BF. In two states, Amazonas and São Paulo, the differences between people from BF households and non-BF households were negative for all variables. There were no states where the pattern of differences between $\mathrm{BF}$ households and non-BF households went in different directions across variables. Also of note, we saw no geographical pattern in the data. That is, there was no apparent similarity within states that were close geographically.

\section{Discussion}

We found that the association between BF status and many health indicators did not indicate that people receiving $\mathrm{BF}$, or living in households that receive $\mathrm{BF}$, had universally worse health indicators. People with BF had much lower rates of health insurance but were simultaneously more likely to have visited a doctor in the previous 12 months, suggesting that this lack of coverage was not preventing them from accessing health services. The increased frequency with which people with BF visit the doctor could indicate that they have more health problems than non-BF people but when examining

\section{Figure 2}

Difference between households receiving and those not receiving payments from the Brazilian Income Transfer Program (Bolsa Familia - BF) in four variables that demonstrated moderate to large heterogeneity between states.

2a) Privatre insurance

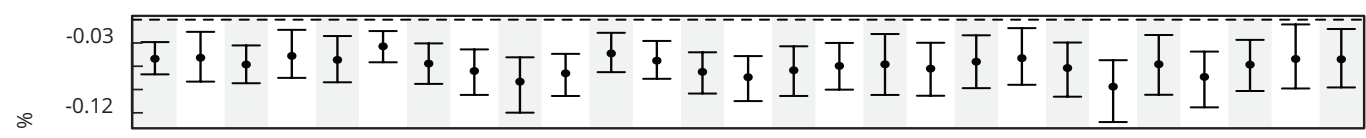

2b) Height

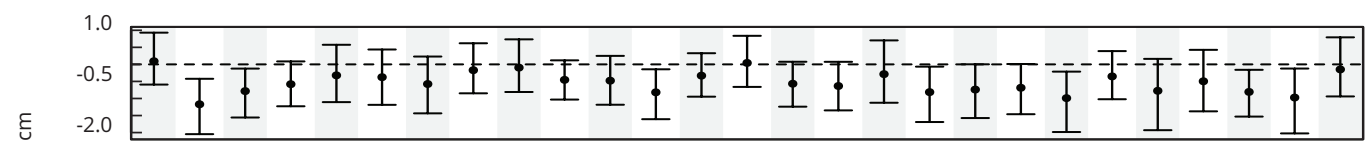

2c) Diabetes

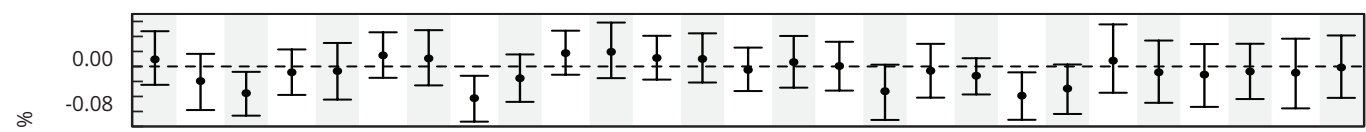

2d) High cholesterol

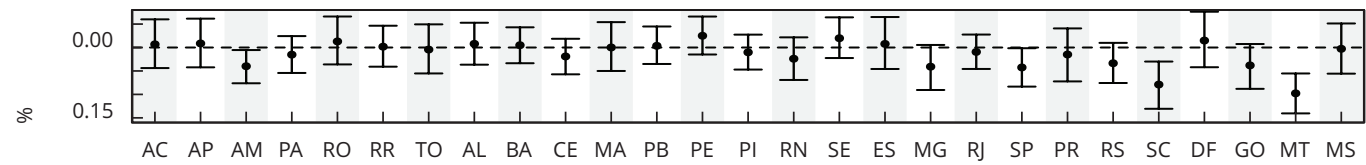

States: AC - Acre; AL - Alagoas; AM - Amazonas; AP - Amapá; BA - Bahia; CE - Ceará; DF - Federal District; ES - Espírito Santo; GO - Goiás; MA - Maranhão; MG - Minas Gerais; MS - Mato Grosso do Sul; MT - Mato Grosso; PA - Pará;

PB - Paraíba; PE - Pernambuco; PI - Piauí; PR - Paraná; RJ - Rio de Janeiro; RN - Rio Grande do Norte; RO - Rondônia; RR - Roraima; RS - Rio Grande do Sul; SC - Santa Catarina; SE - Sergipe; SP - São Paulo; TO - Tocantins. 
health problems, despite people with BF reporting worse self-rated health, they do not report higher rates of any important health problem. In fact, they report lower rates for most conditions.

We also observed moderate to large heterogeneity across Brazilian states in health services use, anthropometrics and health problems. This heterogeneity is seen both in the I-squared statistics and in the magnitude of the difference when comparing states at the extremes of the distributions. For a number of health problems such as diabetes, high cholesterol, asthma, arthritis and having a handicap, there was a qualitative difference between some states; meaning that in some states the BF recipients had higher rates of these health problems and lower rates in other states. This may be because different types of people are either targeted for receiving BF or different types of people are self-selected to receive $\mathrm{BF}$.

This study was the first to examine general health characteristics in terms of medical services use, anthropometrics, health behaviors, nutrition and health problems of people who live in the households that receive BF. This information will benefit policy makers by showing which aspects of their health lack the most among families who receive BF. This study is also the only one that describes whether the relationships between receiving BF and health differ from state to state. This has many important consequences. Firstly, knowledge of which states are doing particularly poorly on certain indicators can be used to target BF households with certain additional programs. Many Brazilian states already have programs that offer BF recipients additional cash transfers or programs. These programs could incorporate state-level knowledge of health issues among BF recipients that need to be addressed. For instance, in the state of Mato Grosso do Sul, BF households had a higher BMI and ate one less serving of fruits and vegetables per week. The state has its own cash transfer program that targets poor families, including BF recipients, whose HPCI still falls under half a minimum wage per capita even after receiving money from BF. The state may consider targeting these groups with nutritional education as well as additional cash transfer. Another example is the state of Goiás whose BF recipients were $1.8 \%$ more likely to smoke and $3.4 \%$ less likely to do exercise. Similar to the previous example, the state could consider additional programs that target health behaviors of BF recipients.

A second important consequence of the heterogeneity between states is that it lends support to the idea that the effects of a cash transfer are sensitive to the setting in which they are implemented. Although only associations were estimated in this study, not causal effects, we demonstrate that there are important differences in the health indicators of people who receive cash transfer within one country. Given that many important health characteristics of participating households, health services use and health problems in particular, differ from state to state, causal effects of the same policy may also differ from the state to state. This has important policy implications as this type of heterogeneity makes it difficult to apply the results from one population to another population.

The most important limitation of our study was the misclassification of BF participation. Although BF status as well as money received from BF was included as a separate question in the survey, when the data were released by the IBGE, this variable was combined with other variables regarding the money received from financial dividends, other social programs and other income sources. While some amount of misclassification is inevitable, we took careful steps to eliminate as much misclassification as possible and to verify that the resulting distribution of payments from the combined variable resembled the distribution observed from the actual BF data. Any misclassification that occurred was most likely misclassification with other cash transfer programs. At the federal level, only two other cash transfers exist. We eliminated one, GS program, by removing BRL 300 payments. The second is a program to prevent child labor and makes up less than $0.1 \%$ of all cash transfer payments in Brazil and therefore is unlikely to influence the results (http://downloads.ibge. gov.br/downloads_estatisticas.htm, accessed on 09/Jan/2017). Some states offer their own cash transfer programs either as a complement to $\mathrm{BF}$ or as a target to other disadvantaged groups not covered by BF. In our study, people receiving money from these programs would have been classified as $\mathrm{BF}$ as well. Because most of these programs share a lot of similarities with BF, classifying people receiving these benefits as having received $\mathrm{BF}$ is unlikely to have an appreciable impact on the results. Alternatively, this group could simply be considered as "exposed to a cash transfer". 


\section{Conclusion}

In conclusion, we observed heterogeneity between Brazilian states indicating important differences in use of health services, anthropometrics and illnesses among households that earn less than BRL 500 per month. The possibility of heterogeneous effects of social programs should therefore be taken into consideration in future research.

\section{Contributors}

J. A. Labrecque had the idea for the article, cleaned the dataset, conducted the analyses, and wrote the manuscript. J. S. Kaufman helped conceiving the article, helped with the analyses and interpretation, and critically reviewed the final manuscript.

\section{Additional informations}

ORCID: Jeremy A. Labrecque (0000-0002-10282158); Jay S. Kaufman (0000-0003-1606-401X).

\section{References}

1. Torrens AW, Rasella D, Boccia D, Maciel EL, Nery JS, Olson ZD, et al. Effectiveness of a conditional cash transfer programme on $\mathrm{TB}$ cure rate: a retrospective cohort study in Brazil. Trans R Soc Trop Med Hyg 2016; 110:199206.

2. Nery JS, Pereira SM, Rasella D, Penna ML, Aquino R, Rodrigues LC, et al. Effect of the Brazilian conditional cash transfer and primary health care programs on the new case detection rate of leprosy. PLoS Negl Trop Dis 2014; 8:e3357.

3. de Lima FEL, Rabito EI, Dias MRMG. Nutritional status of the adult population in the Bolsa Família Program in Curitiba, State of Paraná, Brazil. Rev Bras Epidemiol 2011; 14:198-206.

4. Manley J, Gitter S, Slavchevska V. How effective are cash transfers at improving nutritional status? World Dev 2013; 48:133-55.

5. Morris SS, Olinto P, Flores R, Nilson EA, Figueiró AC. Conditional cash transfers are associated with a small reduction in the rate of weight gain of preschool children in northeast Brazil. J Nutr 2004; 134:2336-41.

6. Fernald LCH, Hidrobo M. Effect of Ecuador's cash transfer program (Bono de Desarrollo Humano) on child development in infants and toddlers: a randomized effectiveness trial. Soc Sci Med 2011; 72:1437-46.

7. Paes-Sousa R, Santos LMP, Miazaki ÉS. Effects of a conditional cash transfer programme on child nutrition in Brazil. Bull World Health Organ 2011; 89:496-503.

\section{Acknowledgments}

We would like to thank Dr. Djalma Pessoa and Anthony Damico for the creation of the R package, which greatly facilitated the analysis of PNS data. We also thank the Canadian Institutes for Health Research through the Frederick Banting and Charles Best Canada Graduate Scholarship, for the financial support.

8. Instituto Brasileiro de Geografia e Estatística. Contas regionais 2014: cinco estados responderam por quase dois terços do PIB do país. https://agenciadenoticias.ibge.gov.br/agenciasala-de-imprensa/2013-agencia-de-noticias/ releases/9460-contas-regionais-2014-cinco -estados-responderam-por-quase-dois-tercosdo-pib-do-pais (accessed on 24/Nov/2016).

9. Brasil. Decreto no 5.209 , de 17 de setembro de 2004. Regulamenta a Lei no 10.836 , de 9 de janeiro de 2004, que cria o Programa Bolsa Família, e dá outras providências. Diário Oficial da União 2004; 20 sep.

10. Souza-Júnior PRB, Freitas MPS, Antonaci GA, Szwarcwald CL. Desenho da amostra da Pesquisa Nacional de Saúde 2013. Epidemiol Serv Saúde 2015; 24:207-16.

11. Szwarcwald CL, Malta DC, Pereira CA, Vieira MLFP, Conde WL, Souza Júnior PRB, et al. Pesquisa Nacional de Saúde no Brasil: concepção e metodologia de aplicação. Ciênc Saúde Colet 2014; 19:333-42.

12. Brasil. Saiba como é a divisão do sistema de educação brasileiro. http://www.brasil.gov.br/ educacao/2014/05/saiba-como-e-a-divisaodo-sistema-de-educacao-brasileiro/view (accessed on 14/Jan/2017).

13. Efron B, Morris C. Stein's paradox in statistics. Sci Am 1977; 236:119-27.

14. Cochran WG. The combination of estimates from different experiments. Biometrics 1954; 10:101-29.

15. Higgins JPT, Thompson SG. Quantifying heterogeneity in a meta-analysis. Stat Med 2002; 21:1539-58 


\section{Resumo}

Os autores investigaram a relação entre pertencimento a uma família beneficiária do programa Bolsa Família (BF) e características de saúde, e se tais relações são heterogêneas, comparando os 26 estados e Distrito Federal, Brasil. De acordo como dados da Pesquisa Nacional de Saúde de 2013, $18 \%$ dos domicílios brasileiros participavam do BF. Entre as familias com renda per capita abai$x o$ de $R \$ 500,00$, havia diferenças entre diversas características de saúde, comparando pessoas de famílias beneficiárias e não beneficiárias do BF. Por exemplo, pessoas de famílias matriculadas no BF mostraram menor probabilidade de ter cobertura médica, mas maior probabilidade de haverem consultado um médico nos últimos 12 meses, além de maior probabilidade de serem fumantes $e$ menor probabilidade de serem fisicamente ativas. Consumiam quase uma porção a menos de frutas e verduras por semana, mas tinham menor probabilidade de substituir refeições com lanches. Apresentavam pior percepção da própria saúde, mas não mostravam diferenças importantes no relato de doenças. Houve uma heterogeneidade moderada nas características de saúde em relação a algumas variáveis. Por exemplo, a cobertura de saúde mostrou um valor de I2 de 40,7\%, enquanto a diferença de cobertura entre familias com e sem BF variou entre 0,09e-0,03. Houve diferenças qualitativas entre estados em relação a algumas doenças, tais como hipercolesterolemia, asma e artrite. Este estudo foi o primeiro a definir o perfil de saúde de pessoas em famílias beneficiárias do BF. Também é o primeiro a encontrar uma heterogeneidade geográfica na relação entre o programa e variáveis de saúde. Os resultados sugerem que o efeito de um programa de renda mínima pode variar de acordo com a população na qual é implementado.

Política de Saúde; Características da População; Programas Governamentais

\section{Resumen}

Investigamos la relación entre vivir en un hogar que recibe ayudas del programa Bolsa Familia (BF), programa brasileño de transferencia monetaria condicionada, y aspectos de salud, además de estudiar si estas relaciones son heterogéneas entre los 27 estados brasileños. De acuerdo con los datos de 2013 en la Encuesta Nacional de Salud brasileña, un $18 \%$ de los hogares participaron en $B F$. Entre los hogares con unos ingresos per cápita por debajo de BRL 500, muchos aspectos de salud difirieron entre la gente que vivía en hogares con $B F y$ sin BF. Por ejemplo, los hogares con BF fueron menos propensos a contar cobertura médica, pero era más probable que hubieran visitado al doctor en los últimos 12 meses, al igual que más probabilidad de fumar y menos propensos a hacer ejercicio. Comían frutas y verduras menos de casi una vez a la semana y eran menos propensos a sustituir la comida basura por una comida. Informaban de una peor salud autoevaluada, pero no difieren significativamente respecto a las enfermedades relatadas. Se encontraron algunas variables de heterogeneidad en cantidades moderadas, respecto a la diferencia en las características de salud. Por ejemplo, la cobertura médica tenía una cobertura con un valor I2 de 40,7\% y la diferencia en la cobertura entre hogares con BFy no-BF oscilaba en un rango de -0.09 a -0.03. Algunas enfermedades se diferenciaban cualitativamente entre estados como el colesterol alto, asma y artritis. Este trabajo es el primero en resaltar el perfil de salud de la gente que vive en hogares que reciben pagos del programa brasileño de transferencia monetaria condicionada. Asimismo, es el primero en encontrar una heterogeneidad geográfica en la relación entre el programa brasileño de transferencia monetaria condicionada y variables de salud. Estos resultados sugieren la posibilidad de que el efecto del programa brasileño de transferencia monetaria condicionada puede ser diferente en función de la población en la que se implementa.

Politica de Salud; Características de la Población; Programas de Gobierno
Submitted on $20 / \mathrm{Jul} / 2018$

Final version resubmitted on 18/Jan/2019

Approved on 31/Jan/2019 